\title{
The Murrumbidgee soil moisture monitoring network data set
}

\author{
A. B. Smith, ${ }^{1,2}$ J. P. Walker, ${ }^{3}$ A. W. Western, ${ }^{1}$ R. I. Young, ${ }^{1}$ K. M. Ellett, ${ }^{1,4}$ \\ R. C. Pipunic, ${ }^{1}$ R. B. Grayson, ${ }^{1}$ L. Siriwardena, ${ }^{1}$ F. H. S. Chiew, ${ }^{5}$ and H. Richter ${ }^{2}$ \\ Received 9 February 2012; revised 6 June 2012; accepted 6 June 2012; published 17 July 2012.
}

[1] This paper describes a soil moisture data set from the $82,000 \mathrm{~km}^{2}$ Murrumbidgee River Catchment in southern New South Wales, Australia. Data have been archived from the Murrumbidgee Soil Moisture Monitoring Network (MSMMN) since its inception in September 2001. The Murrumbidgee Catchment represents a range of conditions typical of much of temperate Australia, with climate ranging from semiarid to humid and land use including dry land and irrigated agriculture, remnant native vegetation, and urban areas. There are a total of 38 soil moisture-monitoring sites across the Murrumbidgee Catchment, with a concentration of sites in three subareas. The data set is composed of $0-5$ (or 0-8), 0-30, 30-60, and 60-90 cm average soil moisture, soil temperature, precipitation, and other land surface model forcing at all sites, together with other ancillary data. These data are available on the World Wide Web at http://www.oznet.org.au.

Citation: Smith, A. B., J. P. Walker, A. W. Western, R. I. Young, K. M. Ellett, R. C. Pipunic, R. B. Grayson, L. Siriwardena, F. H. S. Chiew, and H. Richter (2012), The Murrumbidgee soil moisture monitoring network data set, Water Resour. Res., 48, W07701, doi:10.1029/2012WR011976.

\section{Introduction}

[2] Soil moisture is a critical state variable controlling key physical processes in numerical weather prediction, climate modeling, agricultural crop growth modeling, and flood forecasting. In mesoscale and atmospheric general circulation models, soil moisture controls the partitioning of the energy budget between latent and sensible heat fluxes at the land surface [Entekhabi et al., 1996]. Furthermore, soil moisture information is used in crop growth models to specify the available water for plant root extraction [Kroes et al., 2000], and determines the nature and extent of runoff generation in flood forecasting [Goodrich et al., 1994].

[3] While there are now several long-term soil moisture data sets available worldwide [Dorigo et al., 2011], e.g., the global soil moisture data bank [Robock et al., 2000] and the Oklahoma mesonet [Brock et al., 1995], there are very few Australian (or Southern Hemisphere) examples. Of the Australian soil moisture data sets, the Nerrigundah [Walker et al., 2001] and Tarrawarra [Western and Grayson, 1998] data sets are very comprehensive (including soil moisture time series and spatio-temporal maps) but limited in spatial and temporal extent (catchment areas of 0.06 and $0.105 \mathrm{~km}^{2}$,

\footnotetext{
${ }^{1}$ Department of Infrastructure Engineering, University of Melbourne, Parkville, Australia.

${ }^{2}$ Bureau of Meteorology, Melbourne, Australia.

${ }^{3}$ Department of Civil Engineering, Monash University, Clayton, Australia.

${ }^{4}$ Indiana Geological Survey, Indiana University, Bloomington, Indiana, USA.

${ }^{5}$ CSIRO Land and Water, Canberra, Australia.
}

Corresponding author: A. B. Smith, Department of Infrastructure Engineering, University of Melbourne, Parkville, Australia. (adam.smith@ bom.gov.au)

C2012. American Geophysical Union. All Rights Reserved. 0043-1397/12/2012WR011976 respectively, over $2 \mathrm{yr}$ ). The Goulburn River data set [Rüdiger et al., 2007] covers a much longer period (2002-2007), however, it is limited to a catchment area of $6500 \mathrm{~km}^{2}$ and has no sites within a semiarid climate (which constitutes a significant proportion of Australia). This data note describes the $10 \mathrm{yr}$ and ongoing Murrumbidgee Soil Moisture Monitoring Network (MSMMN) data set from the semiarid to humid $82,000 \mathrm{~km}^{2}$ Murrumbidgee River Catchment.

\section{Overview}

[4] The MSMMN data set primarily constitutes root zone soil moisture (top $90 \mathrm{~cm}$ depth) measured continuously at 38 sites within the $82,000 \mathrm{~km}^{2}$ Murrumbidgee River Catchment. Additionally, soil temperature is measured continuously for various depths at each site, together with precipitation. Land surface model (LSM) forcing data are also available for a large number of sites due to their colocation with Bureau of Meteorology automatic weather stations (AWS). Other data available for a limited number of sites includes soil suction (at 18 sites), soil texture analysis (at 13 sites), and surface fluxes from eddy correlation (at one site for 16 months).

[5] The first 18 sites of the MSMMN were installed from September to November 2001. Eight of the sites were colocated with AWS, while the remaining 10 sites were grouped in two clusters of $150 \mathrm{~km}^{2}$ (the headwaters of Kyeamba and Adelong Creek Catchments). The MSMMN was augmented 2 yr later with 20 more (second generation) soil moisture monitoring sites that also record soil moisture over the root zone, soil temperature at a single depth, and precipitation. The second generation sites were upgraded in 2006 to include $0-5 \mathrm{~cm}$ soil moisture sensors and soil temperature sensors at $2.5 \mathrm{~cm}$. All MSMMN sites are installed as catchment average soil moisture monitoring (CASMM) sites, in accordance with the recommendations of Grayson and Western [1998] (i.e., midslope, in neutrally convergent areas 
with an aspect close to the catchment average). The second generation sites were installed in two focus areas that complement the first generation sites. The first focus area completes instrumentation of the Kyeamba Creek Catchment (extending to the confluence with the Murrumbidgee River), while the second group of sites in the Yanco region are in a (staggered) grid formation to support the usage of remotely sensed soil moisture data (Figure 1).

[6] Recently (August 2009), an additional 24 sites were installed in two $100 \mathrm{~km}^{2}$ focus areas near two second generations sites in the Yanco Region. These newer sites measure surface soil moisture $(0-5 \mathrm{~cm})$ and soil temperature at three depths $(1,2.5$, and $5 \mathrm{~cm})$. These sites have been installed in such a way that they provide validation data at the $\sim 36,9$, and $3 \mathrm{~km}$ scales of the SMAP satellite [Entekhabi et al., 2010].

\section{Scientific Importance and Use of Data}

[7] The MSMMN data can be used for various purposes. For example, the forcing and soil moisture data have been used for land surface model validation and development [Richter et al., 2004].

[8] The MSMMN data is also well suited to studies involving remotely sensed data sets. Using the MSMMN, Ellett et al. [2006] presented a framework to assess the potential of remotely sensed gravity to provide new insight on the hydrology of the Murray Darling Basin. Draper et al. [2009] conducted an evaluation of the AMSR-E satellite soil moisture product. Latent heat flux data from the MSMMN has been used for validation of MODIS-derived evapotranspiration [Guerschman et al., 2009].

[9] The MSMMN sites and data have also been used as the basis of a number of successful field campaigns aimed at developing soil moisture satellite missions using airborne simulators, including the National Airborne Field Experiment in 2006 [Merlin et al., 2008], and more recently the Australian Airborne Cal/val Experiments for SMOS [Peischl et al., 2012], and the Soil Moisture Active Passive Experiments.

[10] While the authors continue to utilize and analyze this data set, it is being made available to the general research community so that it may be used to its fullest potential for land surface model evaluation and development and remote sensing studies.

\section{Catchment Description}

[11] The $82,000 \mathrm{~km}^{2}$ Murrumbidgee River Catchment is located in southern New South Wales $\left(-34^{\circ} \mathrm{S}\right.$ to $-37^{\circ} \mathrm{S}$, $143^{\circ} \mathrm{E}$ to $150^{\circ} \mathrm{E}$ ). The Murrumbidgee Catchment is part of the Murray Darling Basin (MDB), located in eastern Australia (Figure 1 inset) that provides $35 \%$ of Australia's gross value of agricultural production (Australian Bureau of Statistics, Experimental estimates of the gross value of irrigated agricultural production, 2000-01-2008-09 (cat. 4610.0.55.008), 2010, available at http://www.abs.gov.au/AUSSTATS/abs@. nsf/allprimarymainfeatures/1B68337DF0BC480FCA2579560 00E6DF5). This makes the MDB a critical study area for understanding the effect of climate change, drought recurrence, land surface and atmosphere interactions, and feedbacks. It is also clearly an important place to assess the skill of satellites to remotely sense soil moisture. Finally, the diverse climatic, topographic, and land cover characteristics of the Murrumbidgee Catchment, typical of much of Australia, make it an excellent demonstration test bed for land surface model development.

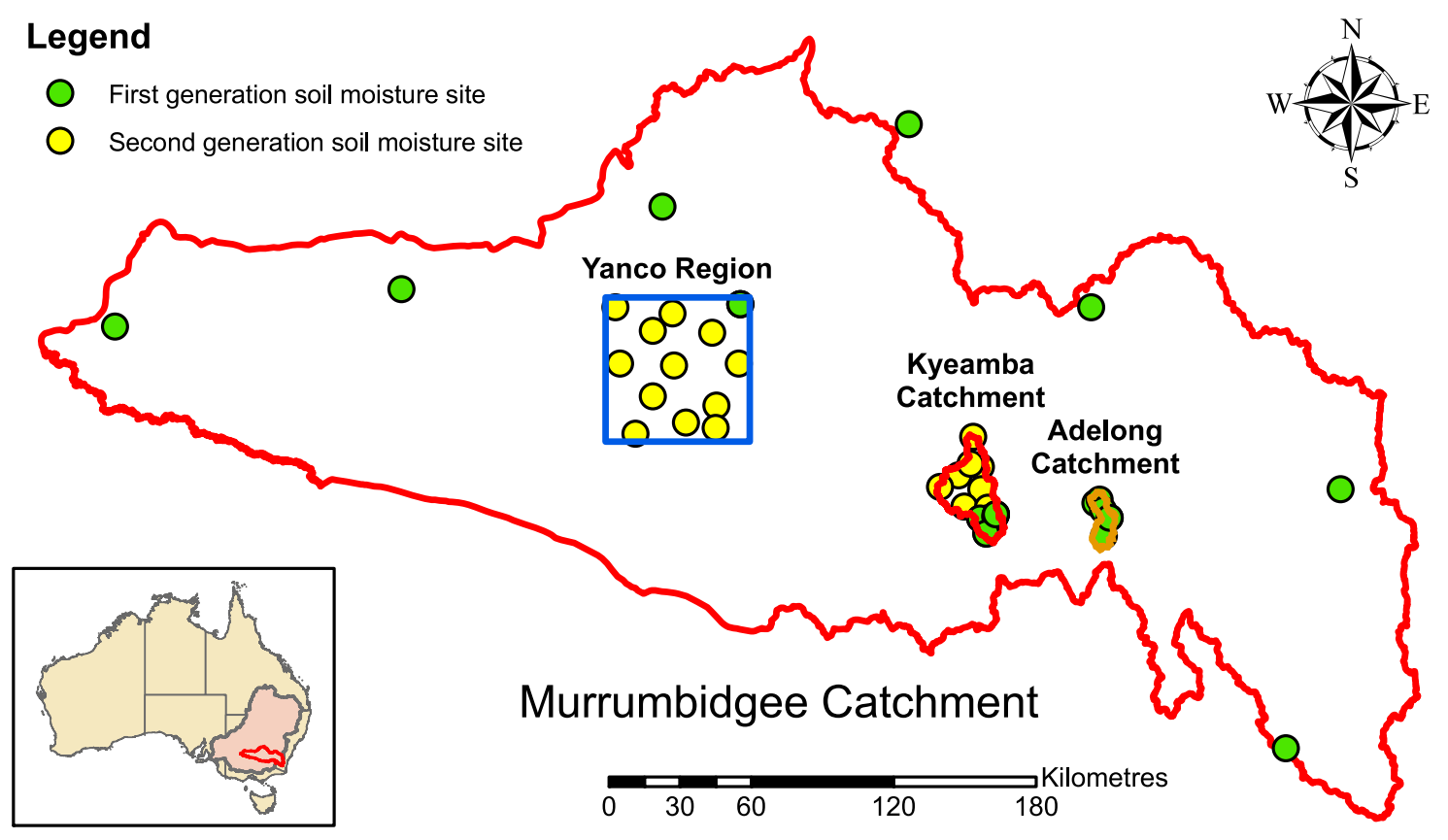

Figure 1. The Murrumbidgee Soil Moisture Monitoring Network (MSMMN) with the Murrumbidgee Catchment and three focus areas shown. First and second generation sites are indicated by green and yellow dots, respectively. Regional Murrumbidgee sites are prefixed with M, likewise Yanco, Kyeamba, and Adelong sites are prefixed with $\mathrm{Y}, \mathrm{K}$, and A (additional information regarding numbering available at http://www.oznet.org.au). The location of the Murrumbidgee Catchment within the Murray Darling Basin and Australia is shown in the inset. 
[12] The Murrumbidgee Catchment shows significant spatial variability in climate, soil, vegetation, and land use. Elevation varies from $50 \mathrm{~m}$ in the west of the catchment to more than $2000 \mathrm{~m}$ in the east. Climate variations are primarily associated with elevation, varying from semiarid in the west, where the average annual precipitation is $300 \mathrm{~mm}$, to humid in the east, where average annual precipitation reaches $1900 \mathrm{~mm}$ in the Snowy Mountains. The mean annual areal actual evapotranspiration in the Murrumbidgee is roughly equivalent to precipitation in the west but represents only half of the precipitation in the east; maximum mean monthly precipitation occurs in the winter and spring.

[13] Soils range from sandy to clayey, with the western plains dominated by finer-textured soils and the eastern half of the catchment by predominantly medium- to coarsetextured soils. Land use in the catchment is predominantly agricultural with the exception of steeper parts of the catchment, which are a mixture of native eucalypt forests and exotic forest plantations. Agricultural land use varies greatly in intensity and includes pastoral, more intensive grazing, broad-acre cropping, and intensive agriculture in irrigation areas along the mid lower Murrumbidgee.

[14] Within the Murrumbidgee River Catchment 31 sites are contained in three focus areas of increasing scale: Adelong Creek Catchment with five sites, Kyeamba Creek Catchment located further west with 13 sites, and the Yanco Region in the western plains with 13 sites (Figure 1). Adelong Creek Catchment is a small catchment $\left(\sim 145 \mathrm{~km}^{2}\right)$ with steep slopes; land use is for sheep and beef grazing. Kyeamba Creek Catchment is a medium to small catchment $\left(\sim 600 \mathrm{~km}^{2}\right)$ where the topography is dominated by gentle slopes; land use is predominantly for sheep and beef grazing with some dairy. The Yanco Region is a large flat area $\left(\sim 2500 \mathrm{~km}^{2}\right)$ with minimal woody vegetation; land use in

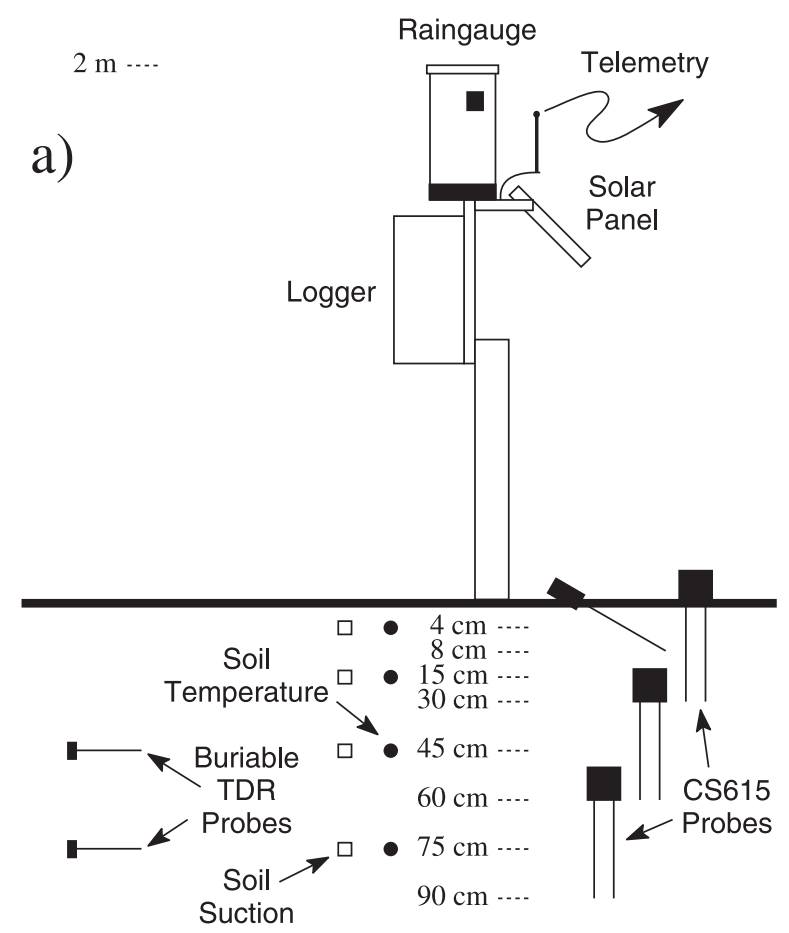

the west of the region comprises irrigation (the Coleambally irrigation area) with rice and barley as the main rotation crops, while elsewhere land use is dry land cropping (predominantly north) and native pasture (south east). The final seven MSMMN sites are located near regional centers throughout the catchment. Further information is available at http://www.oznet.org.au.

\section{Data Summary}

[15] Common to all sites is a tipping bucket rain gauge (Figure 2), three vertically installed Campbell Scientific water content reflectometers that measure soil moisture in the upper $90 \mathrm{~cm}$ of the profile $(0-30,30-60$, and $60-90 \mathrm{~cm})$, a surface soil moisture probe $(0-5$ or $0-8 \mathrm{~cm})$, a soil temperature probe at $15 \mathrm{~cm}$ depth, and a surface temperature probe $(2.5$ or $4 \mathrm{~cm}$ ). Data availability timelines allow a simple visual inspection of data coverage (and gaps) and can be found for each sensor on a site-by-site basis at http://www.oznet.org.au.

[16] Sample data for the year 2005 are shown in Figure 3, where land surface model (CABLE) predictions are also shown for comparison as an example of one use of the MSMMN data. The good agreement in major seasonal signals confirms the integrity of the field data, despite some systematic differences. The LSM wilting point parameter defines the minimum bound of predicted soil moisture (clearly visible in Figure 3). Furthermore, the model uses a single set of soil parameters for the profile, whereas field data supports two distinctly different soil types. This can be attributed to the systematic bias in deeper soil moisture estimates. The specific heat capacity is an estimated parameter that can possibly explain some differences in soil temperature, particularly the much greater diurnal range in the near surface and the slight phase difference for the deeper soil

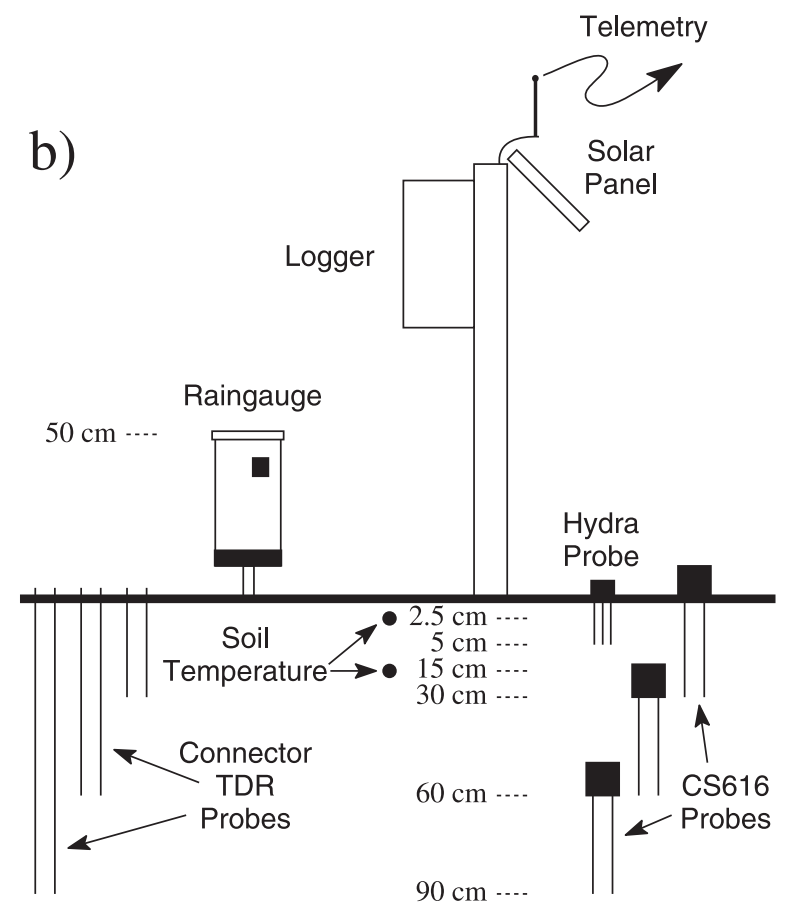

Figure 2. Schematic of the soil moisture monitoring sites: (a) first generation and (b) second generation. 

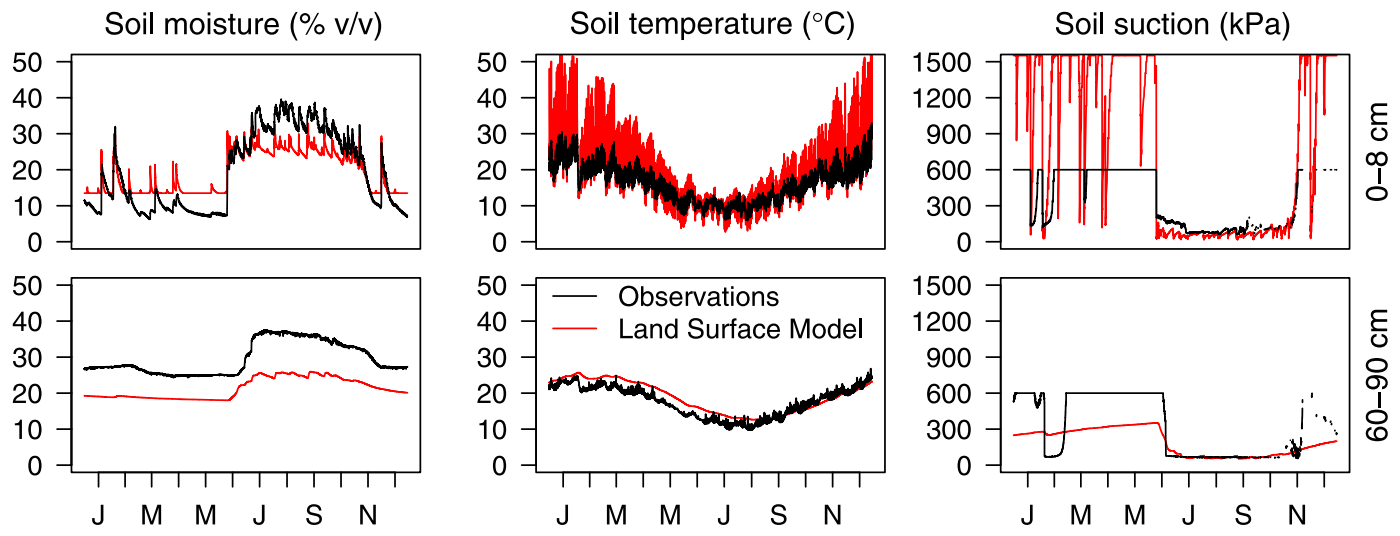

Figure 3. Sample data from a first generation site (K5) for the year 2005. Soil moisture, temperature, and suction are shown in black for two depths (top row: $0-8 \mathrm{~cm}$; bottom row: $60-90 \mathrm{~cm}$ ). Land surface model (CABLE) predictions are shown in red for comparison. The top two layers of the LSM are aggregated to (top row) $0-8 \mathrm{~cm}$, while the fifth layer $(64.3-172.8 \mathrm{~cm})$ is shown with observations from (bottom row) 60-90 cm depth.

temperature. Moreover, the phase difference is likely to also be attributable to the single-point measurement while the LSM approximates a layer of soil. The soil suction observations have a clear upper limit, which is an artifact of the field instrument limitations. However, agreement is good when suction is low during wet periods (June to November). To the author's knowledge this is the first time CABLE soil suction has been compared to in-situ field data.

\subsection{Soil Moisture}

[17] Soil moisture is sampled every 5 or $60 \mathrm{~s}$ then averaged to 30 or $20 \mathrm{~min}$ measurements for first and second generations sites, respectively, using three vertically installed $30 \mathrm{~cm}$ Campbell Scientific water content reflectometers. The 18 first generation sites use CS615 probes, with an additional CS615 inserted at an angle of $\sim 15^{\circ}$ below the surface to give $0-8 \mathrm{~cm}$ soil moisture (Figure $2 \mathrm{a}$ ). As the CS615 model was discontinued in 2002, the newer CS616 (with a higher observing frequency) was installed at the 20 second generation sites, with a $5 \mathrm{~cm}$ long Stevens Hydra Probe vertically inserted at the surface (Figure 2b).

[18] Permanently installed field time domain reflectometry (TDR) probes have been used (with a portable Trase TDR unit) to verify and refine laboratory-based CS615 [Western et al., 2005] and CS616 calibrations [Yeoh et al., 2008]. The CS615 period is temperature corrected to $25^{\circ} \mathrm{C}$ [Western and Seyfried, 2005] using temperature sensors installed at the midpoint of each CS615 probe. The calibration approach of Rüdiger et al. [2010] is used for temperature correction and calibration of the CS616 water content reflectometers. The CS616 temperature correction uses temperature probes at $15 \mathrm{~cm}$ and parameters based on soil texture. The $0-5 \mathrm{~cm}$ Hydra Probe at the second generation sites is calibrated with both laboratory and field gravimetric soil moisture measurements according to the approach of Seyfried et al. [2005] for calibration and that of Merlin et al. [2007] for temperature correction using the temperature probes at $2.5 \mathrm{~cm}$.

[19] The calibration accuracy of the soil moisture probes ranges from a root-mean-square error (RMSE) of $2.5 \% \mathrm{v} / \mathrm{v}$ for the CS615 to $3.3 \%$ v/v for the Hydra Probe (the CS616 accuracy is $3.0 \% \mathrm{v} / \mathrm{v}$ ). For comparison, the "universal" TDR calibration used for the field TDR measurements has an RMSE of $1.3 \% \mathrm{v} / \mathrm{v}$ [Topp et al., 1980]. Calibration reports for the CS615 [Western et al., 2005], CS616 [Yeoh et al., 2008], and Hydra Probe [Merlin et al., 2007] that include parameters for each CS615 and CS616 in the MSMMN are available at http://www.oznet.org.au.

[20] All soil moisture data is $0.1 \% \mathrm{v} / \mathrm{v}$ resolution with a range of $0 \%-50 \% \mathrm{v} / \mathrm{v}$ at all sites (with the exception of 11 probes). The median root zone $(0-90 \mathrm{~cm})$ soil moisture for 2002 or 2004 (first or second generation sites) to 2010 is in the range $11.8 \%-25.5 \% \mathrm{v} / \mathrm{v}$ for the regional Murrumbidgee sites (M1-M7), $18.6 \%-33.0 \% \mathrm{v} / \mathrm{v}$ for the Yanco Region sites (Y1-Y13), 10.3\%-38.6\% v/v for the Kyeamba Creek Catchment sites (K1-K14), and 23.5\%-33.6\% v/v for the Adelong Creek Catchment sites (A1-A5).

[21] Annual median root zone $(0-90 \mathrm{~cm})$ soil moisture is the lowest for all sites in the period 2006-2009. The highest annual median root zone soil moisture is in 2010 (except for 12 sites). Of note is the anomalously high annual median soil moisture at Y4 during 2004 (43.1\% v/v compared to a $2005-2010$ median of $23.6 \% \mathrm{v} / \mathrm{v}$ ) when the site (located in a rice bay) was flood irrigated.

[22] The median soil moisture (over $7 \mathrm{yr}$ ) is spatially consistent among the Yanco Region sites $(22.3 \%-24.9 \% \mathrm{v} / \mathrm{v}$ excluding four sites). Whereas for the Adelong Creek Catchment sites the annual median soil moisture is temporally consistent over 9 yr (e.g., 24.7\%-26.2\% v/v at A3 excluding the years 2006 and 2007). For the Kyeamba Creek Catchment sites median soil moisture (over 7-9 yr) increases from the hillslope to the valley sites (e.g., 11.6\%$25.8 \% \mathrm{v} / \mathrm{v}$ for $\mathrm{K} 1-\mathrm{K} 7$ ).

\subsection{Precipitation}

[23] Cumulative rainfall is recorded every $6 \mathrm{~min}$ at the first generation sites at a height of $2 \mathrm{~m}$, with a precision of $0.2 \mathrm{~mm}$ (Figure 2a). At the second generation sites precipitation at a height of $50 \mathrm{~cm}$ is logged each tip, or each second in periods of high intensity rainfall (Figure 2b). Hydrological Services TB4 $0.2 \mathrm{~mm}$ tipping bucket rain gauges are used at all of the sites (accurate to $3 \%$ at 
intensities of $25-500 \mathrm{~mm} \mathrm{~h}^{-1}$ ). All tipping bucket rain gauge calibrations have been verified with a field calibration device that releases $20 \mathrm{~mm}$ of water uniformly over $\sim 13$ min.

\subsection{Land Surface Model Forcing Data}

[24] Land surface model forcing data (precipitation, air temperature and pressure, relative humidity, wind speed, downward short- and long wave radiation) are available for all sites at $30 \mathrm{~min}$ resolution and are derived primarily from nearby AWS data; details are available at http://www.oznet. org.au. The AWS sites are typically only located near regional centers; consequently, one (regional) forcing data set is available for each of the Yanco, Kyeamba, and Adelong regions with local rainfall provided from the MSMMN site data. Individual forcing data sets are also available for each of M1-M7. The forcing data begins at the start of 2000 (AWS rainfall is used prior to the installation of rain gauges at the MSMMN sites) which allows this year to be used for LSM spin up, and any initialization effects to dissipate before commencement of soil moisture data in late 2001 or early 2004, for first or second generation sites, respectively.

\subsection{Other Data}

[25] Soil temperature is logged every $6 \mathrm{~min}\left(0.1^{\circ} \mathrm{C}\right.$ resolution) at $4,15,45$, and $75 \mathrm{~cm}$ depth at the first generation sites (Figure $2 \mathrm{a}$ ) with a Unidata $6507 \mathrm{~A}$ thermistor $\left(0.35^{\circ} \mathrm{C}\right.$ accuracy) and every $20 \mathrm{~min}$ at 2.5 and $15 \mathrm{~cm}$ depth at the second generation sites (Figure 2b) with a modified Stevens Hydra Probe thermistor $\left(0.6^{\circ} \mathrm{C}\right.$ accuracy) and Campbell Scientific T107 thermistor $\left(0.4^{\circ} \mathrm{C}\right.$ accuracy), respectively. Soil temperature data are required for temperature correcting the soil moisture sensors (Campbell Scientific CS615, CS616, and Stevens Hydra Probe). Where soil temperature data is missing it has been estimated from nearby sites for the soil moisture calibration. Thus, all soil moisture estimates in the MSMMN data set have been temperature corrected, but only the observed temperature data has been included in the data set with the missing data flagged accordingly. The soil temperature measurements at the first generation sites are instantaneous, whereas at the second generation sites they are an average over $20 \mathrm{~min}$ (of instantaneous values sampled every $60 \mathrm{~s}$ ).

[26] Soil suction is measured instantaneously every $30 \mathrm{~min}$ at the first generation sites at the same depths as temperature (Figure 1a) with a MEA GBHeavy gypsum block (range 60$600 \mathrm{kPa}$, resolution $1.5 \%-4 \%$ ).

[27] Soil samples from near the MSMMN sites have been sieved with the material passing $2 \mathrm{~mm}$ analyzed with laser diffraction by CSIRO Minerals using a Malvern Mastersizer 2000 (range $0.02 \mu \mathrm{m}-2 \mathrm{~mm}$ ). The particle size distribution results are aggregated to classes to give the soil texture for most second generation sites (generally at multiple depths).

[28] Surface flux data are available at one site (K10) centrally located in the valley of the Kyeamba Catchment. The flux data are logged every $30 \mathrm{~min}$ from 1 January 2005 to 2 May 2006 and consist of latent and sensible heat flux measured using a CSAT 3-D sonic anemometer and a Licor 7500 gas analyzer $(10 \mathrm{~Hz}$ measurements at $3 \mathrm{~m})$; incoming and outgoing long- and shortwave radiation, measured with a CNR1 Kipp and Zonen instrument located $1 \mathrm{~m}$ above the ground (sensitivity $8.58 \mu \mathrm{V} / \mathrm{W} / \mathrm{m}^{2}$ ), soil heat flux measured with two HFT3 plates and TCAV thermocouple temperature probes $8 \mathrm{~cm}$ below the surface, and air temperature and relative humidity measured with a HMP45C probe at $2 \mathrm{~m}$. Ancillary data measured at the flux site included barometric pressure at $2 \mathrm{~m}$ (accuracy $0.5 \mathrm{mb}$ at $20^{\circ} \mathrm{C}$, range 600-1060 mb), and wind speed and direction at $3 \mathrm{~m}$ measured with a 03001-5 R.M. Young Wind Sentry (anemometer and vane ranges of 0 to $50 \mathrm{~m} \mathrm{~s}^{-1}$ and 0 to $355^{\circ}$, respectively).

\section{Data Quality}

[29] All data from the soil moisture monitoring sites have been visually inspected to identify errors. This checking includes comparisons between soil layers and with rainfall. In addition, tipping bucket rain gauge data has been checked using double-mass plots of daily accumulations to identify periods of faulty gauge operation. Rain gauge catch rates generally agree within 5\%. All detected erroneous data has been removed from the database and flagged as missing. No gap filling of data has been undertaken, with all missing or poor quality data being flagged.

[30] While these data are generally of high and known quality, there are two known artifacts in the data set:

[31] First, the $0-5,0-8$, and $0-30 \mathrm{~cm}$ soil moisture data contain diurnal variations that are possibly due to a residual temperature effect on the soil moisture measurements. These diurnal effects are small (amplitude of $\sim 0.5 \% \mathrm{v} / \mathrm{v}$ ) and well below the measurement accuracy of the data (e.g., $2.5 \% \mathrm{v} / \mathrm{v}$ for the CS615). The diurnal effect is well known [Pepin et al., 1995] for the Hydra Probe [Seyfried and Murdock, 2001; Western and Seyfried, 2005; Seyfried and Grant, 2007] and water content reflectometer [Verhoef et al., 2006; Fernández-Gálvez et al., 2007; Robinson et al., 2008] and seen in other data sets. Soil temperature dependence is a consequence of the low operating frequency of these instruments and an accepted trade off for low instrument cost.

[32] Second, first generation sites have rain gauges installed $2 \mathrm{~m}$ above ground making them vulnerable to some undercatch due to wind effects. Comparisons with daily data from colocated Bureau of Meteorology rain gauges installed below $1 \mathrm{~m}$ (at M1-M7 and Y3) indicate some evidence of an undercatch of $0-0.5 \mathrm{~mm}$ for very small $(<5 \mathrm{~mm})$ rainfall totals at M2, M3, M4, and M7. There is no discernable difference for larger events.

\section{Data Availability}

[33] All data described in this paper are available (in ascii, NetCDF, and spreadsheet formats) via the World Wide Web at http://www.oznet.org.au. The website provides all of the information required for interpretation of these data, along with site photographs, maps, and descriptions. Due acknowledgment in any publication or presentation arising from use of these data is required. Data collection is ongoing as of January 2012 for all sites.

[34] Acknowledgments. Many of the sites are located on privately owned land. The authors wish to thank all property owners for ongoing site access and cooperation. Site installation, maintenance, and sensor calibration has been funded by the Cooperative Research Centre for Catchment Hydrology and Australian Research Council (ARC) Discovery Grants DP0343778, DP0557543, and DP0879212. The ARC Network for Earth System Science provided funding to develop a NetCDF version of the data 
set. A CSIRO-University of Melbourne Collaborative Research Support Scheme Grant supported the flux station maintenance. Installation of recently added surface soil moisture and temperature sites in the Yanco study area were funded by ARC Discovery Grant DP0984586. Field assistance provided by numerous individuals over the past years is gratefully acknowledged, as is direct cash support from University of Melbourne and Monash University.

\section{References}

Brock, F. V., K. C. Crawford, R. L. Elliott, G. W. Cuperus, S. J. Stadler, H. L. Johnson, and M. D. Eilts (1995), The Oklahoma mesonet: A technical overview, J. Atmos. Oceanic Technol., 12, 5-19.

Dorigo, W., et al. (2011), The international soil moisture network: A data hosting facility for global in situ soil moisture measurements, Hydrol. Earth Syst. Sci., 15(5), 1675-1698, doi:10.5194/hess-15-16752011.

Draper, C. S., J. P. Walker, P. J. Steinle, R. A. de Jeu, and T. R. Holmes (2009), An evaluation of AMSR-E derived soil moisture over Australia, Remote Sens. Environ., 113(4), 703-710, doi:10.1016/j.rse.2008.11.011.

Ellett, K., J. Walker, A. Western, and M. Rodell (2006), A framework for assessing the potential of remote-sensed gravity to provide new insight on the hydrology of the Murray-Darling Basin, Aus. J. Water Resour., 10(2), 89-101.

Entekhabi, D., I. Rodriguez-Iturbe, and F. Castelli (1996), Mutual interaction of soil moisture state and atmospheric processes, J. Hydrol., 184, $3-17$.

Entekhabi, D., et al. (2010), The Soil Moisture Active Passive (SMAP) mission, Proc. IEEE, 98(5), 704-716.

Fernández-Gálvez, J., A. Verhoef, and E. Barahona (2007), Estimating soil water fluxes from soil water records obtained using dielectric sensors, Hydrol. Processes, 21, 2785-2793, doi:10.1002/hyp.6494.

Goodrich, D., T. Schmugge, T. Jackson, C. Unkrich, T. Keefer, R. Parry, and S. Amer (1994), Runoff simulation sensitivity to remotely sensed initial soil water content, Water Resour. Res., 30, 1393-1405.

Grayson, R. B., and A. W. Western (1998), Towards areal estimation of soil water content from point measurements: Time and space stability of mean response, J. Hydrol., 207, 68-82.

Guerschman, J. P., A. I. Van Dijk, G. Mattersdorf, J. Beringer, L. B. Hutley, R. Leuning, R. C. Pipunic, and B. S. Sherman (2009), Scaling of potential evapotranspiration with MODIS data reproduces flux observations and catchment water balance observations across Australia, J. Hydrol., 369, 107-119.

Kroes, J., J. Wesseling, and J. V. Dam (2000), Integrated modelling of the soil-water-atmosphere-plant system using the model SWAP 2.0 an overview of theory and an application, Hydrol. Processes, 14, 1993-2002.

Merlin, O., J. Walker, R. Panciera, R. Young, J. Kalma, and E. Kim (2007), Soil moisture measurements in heterogeneous terrain, in MODSIM07. International Congress on Modelling and Simulation, edited by L. Oxley and D. Kulasiri, pp. 2604-2610, MSSANZ, Canberra, Australia.

Merlin, O., et al. (2008), The NAFE'06 data set: Towards soil moisture retrieval at intermediate resolution, Adv. Water Resour., 31(11), 14441455, doi:10.1016/j.advwatres.2008.01.018.
Peischl, S., J. P. Walker, C. Rüdiger, N. Ye, Y. H. Kerr, E. Kim, R. Bandara, and M. Allahmoradi (2012), The AACES field experiments: SMOS calibration and validation across the Murrumbidgee River catchment, Hydrol. Earth Syst. Sci., 16, 1697-1708, doi:10.5194/hess-16-1697-2012.

Pepin, S., N. Livingstone, and W. Hook (1995), Temperature-dependent measurement errors in time domain reflectometry determinations of soil water, Soil Sci. Soc. Am. J., 59, 38-43.

Richter, H., A. Western, and F. Chiew (2004), The effect of soil and vegetation parameters in the ECMWF land surface scheme, J. Hydrometeor., 5 , 1131-1146.

Robinson, D. A., C. S. Campbell, J. W. Hopmans, B. K. Hornbuckle, S. B. Jones, R. Knight, F. Ogden, J. Selker, and O. Wendroth (2008), Soil moisture measurement for ecological and hydrological watershed-scale observatories: A review, Vadose Zone J., 7, 358-389.

Robock, A., K. Y. Vinnikov, G. Srinivasan, J. K. Entin, S. E. Hollinger, N. A. Speranskaya, S. Liu, and A. Namkhai (2000), The global soil moisture data bank, Bull. Amer. Meteor. Soc., 81(6), 1281-1299.

Rüdiger, C., G. Hancock, H. M. Hemakumara, B. Jacobs, J. D. Kalma, C. Martinez, M. Thyer, J. P. Walker, T. Wells, and G. R. Willgoose (2007), Goulburn River experimental catchment data set, Water Resour. Res., 43, W10403, doi:10.1029/2006WR005837.

Rüdiger, C., A. W. Western, J. P. Walker, A. B. Smith, J. D. Kalma, and G. R. Willgoose (2010), Towards a general equation for frequency domain reflectometers, J. Hydrol., 383, 319-329.

Seyfried, M., and L. Grant (2007), Temperature effects on soil dielectric properties measured at 50-MHz, Vadose Zone J., 6, 759-765.

Seyfried, M., and M. Murdock (2001), Response of a new soil water sensor to variable soil, water content, and temperature, Soil Sci. Soc. Am. J., 65, 28-34.

Seyfried, M., L. Grant, E. Du, and K. Kumes (2005), Dielectric loss and calibration of the Hydra Probe soil water sensor, Vadose Zone J., 4, 1070-1079.

Topp, G., J. Davis, and A. Annan (1980), Electromagnetic determination of soil water content: Measurement in coaxial transmission lines, Water Resour. Res., 16, 574-582.

Verhoef, A., J. Fernández-Gálvez, A. Diaz-Espejo, B. Main, and M. El-Bishti (2006), The diurnal course of soil moisture as measured by various dielectric sensors: Effects of soil temperature and the implications for evaporation estimates, J. Hydrol., 321, 147-162.

Walker, J., G. Willgoose, and J. Kalma (2001), The Nerrigundah data set: Soil moisture patterns, soil characteristics, and hydrological flux measurements, Water Resour. Res., 37(11), 2653-2658.

Western, A. W., and R. Grayson (1998), The Tarrawarra data set: Soil moisture patterns, soil characteristics, and hydrological flux measurements, Water Resour. Res., 34(10), 2765-2768.

Western, A., and M. Seyfried (2005), A calibration and temperature correction procedure for the water content reflectometer, Hydrol. Processes, 19(18), 3785-3793.

Western, A., R. Young, and F. Chiew (2005), Murrumbidgee Soil Moisture Monitoring Network Field Calibration, 16 pp., Cooperative Research Centre for Catchment Hydrology, Canberra, Australia.

Yeoh, N., J. Walker, R. Young, C. Rüdiger, A. Smith, K. Ellett, R. Pipunic, and A. Western (2008), Calibration of the Murrumbidgee Monitoring Network CS616 Soil Moisture Sensors, 21 pp., Dept. of Civil and Environmental Eng., The Univ. of Melbourne, Australia. 


\section{University Library}

\section{- M M N E R VA A gateway to Melbourne's research publications}

Minerva Access is the Institutional Repository of The University of Melbourne

\section{Author/s:}

Smith, AB;Walker, JP;Western, AW;Young, RI;Ellett, KM;Pipunic, RC;Grayson,

RB;Siriwardena, L;Chiew, FHS;Richter, H

Title:

The Murrumbidgee soil moisture monitoring network data set

Date:

2012-07-17

\section{Citation:}

Smith, A. B., Walker, J. P., Western, A. W., Young, R. I., Ellett, K. M., Pipunic, R. C., Grayson, R. B., Siriwardena, L., Chiew, F. H. S. \& Richter, H. (2012). The Murrumbidgee soil moisture monitoring network data set. Water Resources Research, 48 (7), https:// doi.org/10.1029/2012WR011976.

Persistent Link:

http://hdl.handle.net/11343/297409 